\title{
EFFECT OF DICLOFENAC SODIUM IN BROILERS
}

\author{
R. Akhter and M. A. W. Sarker \\ Department of pharmacology, Faculty of Veterinary Science, Bangladesh Agricultural University \\ Mymensingh-2202, Bangladesh
}

\begin{abstract}
This study was conducted to determine the effects of diclofenac sodium in broiler chicks during the period from $20^{\text {th }}$ July $/ 2012$ to $1^{\text {st }}$ september/2012. The broiler chicks were divided into four groups A, B, C and control with ten day old bird in each. Group A was treated with @ 5mg/kg body weight, group B was treated with @ 10mg/kg body weight and Group C was treated with $20 \mathrm{mg} / \mathrm{kg}$ body weight given orally mixing with drinking water. Histopathological, hematological and biochemical tests were performed on $42^{\text {th }}$ days of age to evaluate diclofenac-induced changes between control and treated groups. Mortality rate and pathomorphological changes were observed in dead birds. The acute toxicity was assessed by observing the clinical signs and symptoms, mortality, alterations in blood biochemistry, and necropsy findings. The birds of Group A showed only mild symptoms of diarrhea and 30\% mortality. In Group B, $60 \%$ and Group $70 \%$ of birds died in between 24 and $36 \mathrm{~h}$ post-treatment showing the symptoms of segregatory behavior, lethargy, terminal anorexia, and severe bloody diarrhea. Observation of hematological parameters like TEC, Hb, PCV and ESR on $42^{\text {th }}$ days of age showed significant $(\mathrm{p}<0.01)$ decrease in treatment group compare to control group. Observation of biochemical parameters (serum urea, serum creatinine) on $42^{\text {th }}$ days of age showed significantly increased $(\mathrm{p}<0.01)$ serum urea and serum creatinine indicating nephrotoxicity in broilers. At 12 and $24 \mathrm{~h}$ post-treatment this returned to the normal levels. The dead birds of the high-dose group also showed similar pattern of biochemical changes at 12 and $24 \mathrm{~h}$ post-treatment and revealed extensive visceral gout with characteristic histopathological lesions in liver, kidney, heart, spleen and intestine on post-mortem. The results indicate that diclofenac sodium has hepatotoxic, nephrotoxic, and visceral gout inducing potentials in broilers (cob-500), especially at higher dose.
\end{abstract}

Key words: Pathological effects, diclofenac sodium, hematological parameters, biochemical parameters, visceral gout, nephrotoxicity, broilers

\section{INTRODUCTION}

Diclofenac sodium is unique among the NSAIDs in that it possesses the mechanism of action for the inhibition of arachidonic acid cyclooxygenase system, lipooxygenase pathway, and arachidonic acid release resulting in decreased production of prostaglandins and thromboxanes, leukotrienes and reduction of arachidonic acid respectively (Martindale and Sweetman, 2002). This drug has an inhibitory effect on prostaglandin synthesis and is used as an initial therapy for inflammatory and degenerative rheumatic diseases as well as for pain conditions such as musculoskeletal and post-operative pains and acute attacks of gout and ureteric colic (Morgan, 1999; Perttunun et al., 1999). Diclofenac sodium causes a rare but potentially fetal hepatotoxicity that may be associated with the formation of reactive metabolites and subsequent adverse hepatitis effects may arise in certain individuals (Ouellette et al., 1991, Bhogaraju et al., 1999). NSAIDs are characterized by the ability to inhibit cyclo-oxygenase enzymes, which are involved in the formation of prostaglandins. However, there are marked differences between drugs in their selective inhibition of the two subtypes of cyclo-oxygenase, COX-1 and COX-2, the latter being involved with the modulation of inflammation-mediated responses and pain, while the former modulates blood flow to the kidneys. The ability of NSAIDs to inhibit both these subtypes has been implicated as a cause of the side effects occasionally associated with the use of some NSAIDs. Toxic effects on the kidneys of vultures have been observed with number of NSAIDs (Anderson et al., 2005). The widespread use of diclofenac sodium in veterinary medicine has been linked to near extinction of vultures in the Indian subcontinent, and as such the drug has been withdrawn from veterinary use in the year 2006. Vulture deaths were reported to be due to severe renal damage causing visceral gout following scavenging on dead livestock treated shortly before death (Oaks et al., 2004). The aetiopathology of diclofenac-induced visceral gout in vultures is not conclusively understood. Though there are no published reports of using diclofenac as such in poultry birds, a 


\section{R. Akhter and M. A. W. Sarker}

wide variety of indications (trauma, coccidiosis, heat stress, and pain related to beak trimming) (Baert et al., 2003; Danbury et al., 1997; Glatz et al., 1992; Oliver et al., 1981) exist for which treatment with other NSAIDs could be beneficial in bird medicine. The present study was planned with the objective to evaluate the acute oral toxicity of diclofenac sodium in broilers and to assess whether diclofenac is also similarly toxic to these birds as reported in vultures. The present study was performed to effects of diclofenac in the clinical, histological, pathological, biochemical parameters and post-mortem lesions of broilers.

\section{MATERIALS AND METHODS}

The present research was conducted during the period from $20^{\text {th }}$ July $/ 2012$ to $1^{\text {st }}$ September/2012 in the Department of Pharmacology and Pathology Laboratory, BAU, Mymensingh. Diclofenac drugs were collected from K.R. market, Bangladesh Agricultural University (BAU). A total of 40 apparently healthy day old broiler chicks (cobb-500 strain) were procured for the study from the nourish poultry hatchery. The experiment was conducted according to the completely randomized design and data about per replicate body wt., weekly body wt., and mortality were recorded during the experimental period (1-6 weeks of age). Group A, B and C were supplemented with Diclofenac sodium orally mixing with drinking water. Birds of group A were received 5 $\mathrm{mg} / \mathrm{kg}$ body weight orally and group B birds were received Diclofenac tablet (A-FENAC VET containing 100 $\mathrm{mg}$ diclofenac sodium of ACME Bangladesh limited, Dhaka)), $10 \mathrm{mg} / \mathrm{kg}$ body weight orally. Group C birds were received Diclofenac sodium containing tablet, $20 \mathrm{mg} / \mathrm{kg}$ body weight Single oral dose. Diclofenac dose started at $28^{\text {th }}$ days, $29^{\text {th }}$ days of birds and $41^{\text {th }}$ days of broiler because of the withdrawn period of drugs. For all groups, weekly observation of Body weight, Clinical signs, Mortality rate. After $42^{\text {nd }}$ days birds were sacrificed and blood and organ are collected for Blood Hematological parameters-(TEC, PCV, ESR, $\mathrm{Hb} \%$ ), Serum biochemistry -(Serum Urea, Serum Creatinine), Organs (Kidney, liver, Spleen, Heart, Lungs, Intestine) collected for histopathology and post mortem findings (gross pathogens). For studying biochemical values, blood was collected directly from the wing vein at 42 day of experiment by puncturing with disposable needle. For studying hematological values, blood was collected at slaughtering, in a sterile test tube containing anticoagulant (4\% sodium citrate solution) at a ratio of 1:10. The hematological studies were performed within two hours of the blood collection. Plasma was separated immediately by centrifugation and stored at $-20^{\circ} \mathrm{C}$ until analyzed. After drug administration, the birds were observed for onset, nature, and severity of clinical symptoms and mortality, if any, up to seventh day post-administration. Blood samples were also analyzed for estimation of Total leukocyte count (TLC), Hemoglobin (Hb), Erythrocyte Sedimentation Rate (ESR), Packed cell Volume (PCV) in laboratory, Serum for urea and creatinine in plasma by using Reflotron ${ }^{\circledR}$ auto analyzer (Boehringer Mannheim). All the biochemical tests were performed at $37^{\circ} \mathrm{C}$. All the birds, which died due to toxicity of diclofenac in Group A, B and A were autopsied and the surviving birds of Groups A, B and C were sacrificed and subjected to pathological investigations.

\section{Statistical analysis}

The data were analyzed statistically between control and treated groups of chicken by the analysis of variance (ANOVA) technique in completely randomized design. The significance in difference was accepted at $\mathrm{P}<0.01$ (Snedecor et al., 1967).

\section{RESULT AND DISCUSSION}

Birds of Control group did not show any signs and symptoms of toxicity. Birds of Group A, B and C showed mild to severe diarrhea, dullness, segregatory behavior, blood tinged diarrhea, and anorexia before death. Diclofenac sodium play significant clinical signs caused 30\% mortality rate in group A, 60\% mortality in group B and 70\% mortality in group C (Table 1). Survived birds of group C had only blood-tinged diarrhea.

Table 1. Effect of Diclofenac sodium on Mortality rate of broiler birds

\begin{tabular}{lllll}
\hline Day of the Experiment & Group A & Group B & Group C & Control \\
\hline $29^{\text {th }}$ day & 1 & 3 & 1 & -------- \\
$30^{\text {th }}$ day & 1 & 2 & 3 & -------- \\
$31^{\text {st }}$ day & - & - & 1 & ------- \\
$42^{\text {nd }}$ day & 1 & 1 & 2 & ------ \\
\hline
\end{tabular}


The acute toxicity of diclofenac sodium was studied by many workers in avian species. $40 \%$ mortality was observed in Vanraja and PB1 birds within 12 days following inoculation of diclofenac sodium in the dose of 5 $\mathrm{mg} / \mathrm{kg}$ (Reddy et al., 2006). Diclofenac sodium, $0.8 \mathrm{mg} / \mathrm{kg}$ was highly toxic to Gyps fulvus and G. africanus species of vultures and the oral LD50 of diclofenac in G. bengalensis were found to be $0.1-0.2 \mathrm{mg} / \mathrm{kg}$ (Taib et al., 2004). In the present study, each group contains 10 broiler birds.

Group A, dose $5 \mathrm{mg} / \mathrm{kg}$, p.o, caused -Death of Birds 3, at the end of experiment mortality $30 \%$

Group B, dose 10mg/kg, p.o, caused- Death of Birds 6, percent (\%) of mortality 60

Group C, dose 20mg/kg, p.o, caused- Death of Birds 7 percent (\%) of mortality 70 in broiler birds. The results indicate that diclofenac is toxic to these birds.

Significant $(\mathrm{p}<0.01)$ differences were observed in hematological parameters between treatment groups and control group. Significant $(\mathrm{p}<0.01)$ decreased in $\mathrm{RBC}, \mathrm{Hb}(\mathrm{gm} \%), \mathrm{PCV}, \mathrm{ESR}$ value in treatment groups compare to control group (Table 2).

Table 2. Effect of Hematological test on Computation of mean values along with standard deviation of some hematological parameters corresponding to the different groups

\begin{tabular}{lllllll}
\hline & \multicolumn{4}{c}{ Treatments (Mean \pm SD) } & \multicolumn{2}{c}{$\begin{array}{l}\text { Level of } \\
\text { significance }\end{array}$} \\
\cline { 2 - 6 } & Group-A & Group-B & Group-C & Control & LSD & $*$ \\
RBC Million/cumm & $2.90 \pm 0.05 \mathrm{~b}$ & $2.85 \pm 0.16 \mathrm{~b}$ & $2.81 \pm 0.10 \mathrm{~b}$ & & 0.11 & $*$ \\
$\mathrm{Hb}(\mathrm{gm} \%)$ & $7.87 \pm 0.12 \mathrm{~b}$ & $7.80 \pm 0.28 \mathrm{~b}$ & $7.75 \pm 0.25 \mathrm{~b}$ & $8.15 \pm 0.10 \mathrm{a}$ & 0.24 & $* *$ \\
$\mathrm{PCV} \%(30 \mathrm{~min})$ & $21.67 \pm 1.15 \mathrm{~b}$ & $21.00 \pm 1.41 \mathrm{~b}$ & $20.00 \pm 1.15 \mathrm{c}$ & $22.50 \pm 1.29 \mathrm{a}$ & 1.24 & $* *$ \\
$\mathrm{ESR}(\mathrm{mm}) 1 \mathrm{st}$ hour & $3.75 \pm 1.26 \mathrm{~b}$ & $3.50 \pm 0.71 \mathrm{~b}$ & $3.33 \pm 1.15 \mathrm{~b}$ & $5.50 \pm 1.29 \mathrm{a}$ & 1.57 & $*$ \\
\hline
\end{tabular}

$*=$ Significant at $5 \%$ level of probability $(\mathrm{p}<0.05)$

$* *$ Significant at $1 \%$ level of probability $(\mathrm{p}<0.01)$

$\mathrm{NS}=$ Not significant $(\mathrm{p}>0.05)$

In a column figures with same letter or without letter do not differ significantly whereas figures with dissimilar letter differ significantly (as per DMRT).

Table 3. Effect of Biochemical test on Serum urea and Serum creatinine (Mean \pm SD) of the different groups

\begin{tabular}{lll}
\hline & \multicolumn{1}{c}{$($ Mean \pm SD) } \\
\cline { 2 - 3 } Treatments & S. Urea $(\mathrm{mg} / \mathrm{dl})$ & S. Creatinine $(\mathrm{mg} / \mathrm{dl})$ \\
\hline Group-A & $22.00 \pm 6.68 \mathrm{~b}$ & $0.33 \pm 0.15$ \\
Group-B & $27.50 \pm 3.54 \mathrm{a}$ & $0.35 \pm 0.07 \mathrm{~b}$ \\
Group-C & $28.00 \pm 6.08 \mathrm{a}$ & $0.43 \pm 0.23 \mathrm{a}$ \\
Control & $20.25 \pm 1.71 \mathrm{~b}$ & $0.30 \pm 0.08 \mathrm{~b}$ \\
LSD & 2.44 & 0.041 \\
Level of significance & $* *$ & $*$ \\
\hline
\end{tabular}

$*$ = Significant at $5 \%$ level of probability $(\mathrm{p}<0.05)$

$* *=$ Significant at $1 \%$ level of probability $(\mathrm{p}<0.01)$

Observation of hematological parameters (RBC, Hb, PCV, and ESR) on 42 day showed the significant differences $(\mathrm{P}<0.01)$ those are:-

In dose dependant significant reductions in TEC, $\mathrm{Hb}(\%), \mathrm{PCV}, \mathrm{MCV}, \mathrm{MCHC}$ were ovserved in swiss albino mice (Basavraj SB et al., 2012) in the present study.

In case of TEC, $\mathrm{Hb}$ (gm \%), PCV, ESR level decrease in treatment groups depend on dose of drug compare to control group. Higher dose decreases hematological parameters compare to lower dose treated groups. 


\section{R. Akhter and M. A. W. Sarker}

Clinical gout in chicken was reported when serum uric acid level exceeded $25.5 \mathrm{mg} / \mathrm{dl}$ as compared to 4.2-6.4 $\mathrm{mg} / \mathrm{dl}$ in the control birds (Uma et al., 1999). The increased level of uric acid was found as high as 140 and 160 $\mathrm{mg} / \mathrm{dl}$, at 12 and $24 \mathrm{~h}$ after administration of diclofenac, $0.8 \mathrm{mg} / \mathrm{kg}$ orally in G. Africanus vultures (Swan et al., 2005).

In a column figures with same letter or without letter do not differ significantly whereas figures with dissimilar letter differ significantly (as per DMRT).

In present observation of biochemical parameters (serum urea, serum creatinine) on 42 th days of age showed significant increase in treatment group $\mathrm{C}$ than those of control group resulting nephrotoxicity (Table 3).

Serum urea, Serum creatinine level high in Group C, Compare to control, group A, group B.

\section{Pathological changes}

Diclofenac causes a rare but potentially fatal hepatotoxicity that may be associated with the formation of reactive metabolites (benzoquinones imines) via a hepatic cytochrome P450 catalyzed oxidation which contribute to diclofenac-mediated hepatic injury (Tang et al., 1999) The histopathological changes observed in the present study on various organs are similar to the already existing reports. ( Patel et al., 2007, Arun et al., 2004, Meteyer et al., 2005, Aydin et al., 2002) in present study.

\section{Gross pathology}

Control groups birds did not show any gross pathological lesions. The dead birds of Group C on post-mortem showed extensive visceral gout characterized by congestion, friable in consistency, chalky white crystalline powderd deposition on the surface of the liver (Fig 1). Fatty syndroms, gelatinous fat and white color fat present in heart (Fig 2). Congestion and white crystalline substances present in kidney (Fig 3). Spleen and intestine Haemorrhage and congestion. It produces significant patho morphological lesions and urate deposition in liver and kidney in gross section.

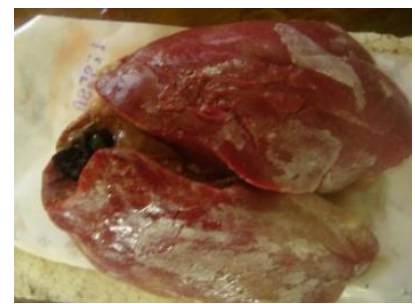

Fig 1. White crystalline powder present over the surface of the liver in broiler

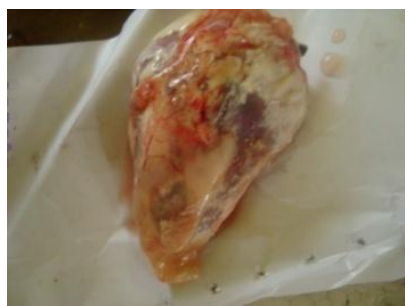

Fig 2. Fatty syndromes, gelatinous fat and white color fat present in heart in broiler

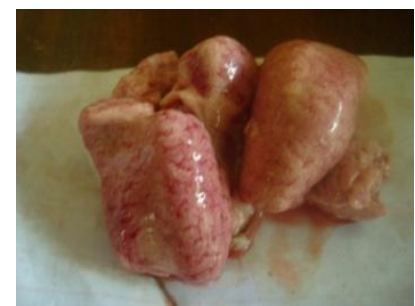

Fig 3. Congestion and white crystalline substances present in kidney

\section{Histopathology}

The liver, kidney, heart, spleen, and intestine sections of Control group birds did not show any histopathological lesion.

\section{Liver}

The liver section of group C and group B showed congestion and hemorrhage in the liver. Liver section of group A showed hemorrhage and necrosis present in liver (10x). Necrotic tissue present in liver (40x) (Fig 4).

\section{Kidney}

The kidney section of birds of Group C, A, B showed tubular degeneration, urate deposition present in kidney tubules. The section of birds of group C, B, A which succumbed to toxicity showed tubular degeneration and varying sized foci of urate deposition (tophi) either in the form of amorphous material or in the radiating crystalline pattern mixed with necrotic debri due to degeneration of surrounding cells (Fig 5). 


\section{Spleen}

Spleen section of dead bird of group $\mathrm{C}$ showing radiating necrotic mass indicating area deposited with urate crystals (10x) (Fig 6). Group A, Group B did not show any lesion.

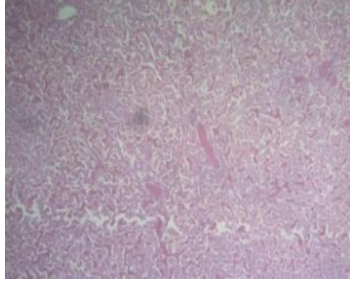

Fig 4. Liver section of dead bird of group C showing severe hemorrhage and congestion $(\mathrm{H} \& \mathrm{E}, 10$ $\mathrm{x})$

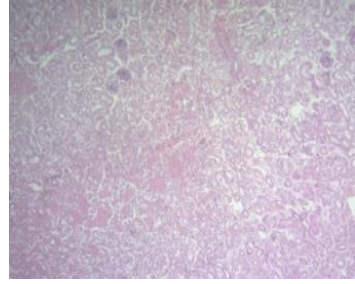

Fig 5. Kidney section of dead bird of group $\mathrm{C}$ dead bird of group $\mathrm{C}$ showing tubular showing radiating degeneration and urate necrotic mass indicating deposition in kidney area deposited with urate tubules lesion $(\mathrm{H} \& \mathrm{E}, 10$ crystals $(\mathrm{H} \& \mathrm{E}, 10 \mathrm{x})$ tubules lesion $(\mathrm{H} \& \mathrm{E}, 10$
$\mathrm{x})$ congestion $(\mathrm{H} \& \mathrm{E}, 10$ $\mathrm{x})$
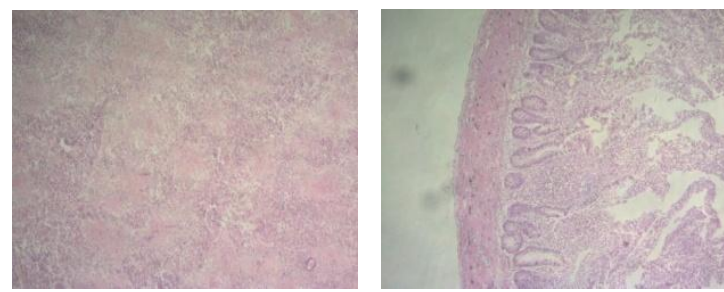

Fig 7. Intestine section of dead bird of group, C showing haemorrhage and internal layer $(\mathrm{H} \& \mathrm{E}, 10$ $\mathrm{x})$

\section{Intestine}

Intestine section of dead bird of Group $C$ showed hemorrhage and congestion (10x). Inflammatory cell present in intestine of group C (40X) (Fig 7). Group A, Group B did not show any lesion.

In conclusion, Diclofenac sodium reduces body weight significantly along with significant effects on hematological and biochemical parameters in broiler. However, this research work was on short-term basis and in absence of modern equipment. An extensive research and development work should be undertaken on diclofenac sodium drugs and its products to make toxicity. The finding more accurately and effectively.

\section{REFERENCE}

1. Ali S and Ripley SD (1968). Handbook of the Birds of India and Pakistan Together with Those of Nepal, Bhutan, and Ceylon. I. Divers and Hawks. Oxford University Press, Oxford.

2. Anderson MD, Piper SE and Swan GE (2005). Non-steroidal anti-inflammatory drug use in South Africa and possible effects on vultures. South African Journal of Animal Science 101: 112-114.

3. Arun PR and Azeez PA (2004). Vulture population decline, diclofenac and avian gout. Current Science 87: 565-68.

4. Aydin G, Gokcimen A, Cicek E, Karahan N and Gokalp O (2002). Histologic Changes in Liver and Kidney Tissues Induced by Different Doses of Diclofenac Sodium in Rats. Turkish Journal of Veterinary and Animal Sciences 27 : 1131-40.

5. Baert K (2003). Pharmacokinetics and Pharmacodynamics of Non steroidal anti-inflammatory drugs. PhD Thesis, Department of Pharmacology, Pharmacy and Toxiclogy, Saliburylaan 133, B-9820 Merelbeke.

6. Basavraj SB, Fefar DT, Prajapati KS, Jivani BM, Thakor KB, Patel JH, Ghodasara DJ, Joshi BP,Undhad VV (2012). Haemato-biochemical alterations induced by Diclofenac sodium toxicity in swiss albino mice. Veterinary world 5: 417-419.

7. Bhogaraju A, Nazeer S, Al-Baghdadi Y, Rahman M, Wrestler F and Patel N (1999). Diclofenac-associated Hepatitis. Journal of South Mediterian 7: 711-713.

8. Bort H, Huber R, Steinijans VW, Koch HJ, Wurrst W and Mascher H (1991). Comparative Metabolism of the Nonsteriodal Anti-inflammatory Drug, Diclofenac, in the Rat, Monkey and Human. Drug Metabolism and Disposition pp. 969-975.

9. Bort R, Ponsoda X, Jover R, Gomez-Lechon MJ and Castell JV (1999). Diclofenac Toxicity to Hepatocytes, A Role for Drug Metabolism in Cell Toxicity. Journal of Pharmacology and Experimental Therapeutics 165-172.

10. Danbury TC, Weeks CA, Chambers JP, Waterman-Pearson AE and Ketsin SC (1997). Self selection of analgesic drug caprofen by lame broilers. Veterinary Record 146: 307-311. 
Akhter and M. A. W. Sarker

11. Gabry MS, Elewa FH and Ibrahim MA (1999). Histochemical Evaluation of the Hepatic and Intestinal Damage Associated with Diclofenac Administration, A Light and Electron Microscopic Study. Egyptian German Society of Zoology 27: 117-153. R.

12. Glatz PC, Murphy LB and Preston AP (1992). Analgesic therapy of beak-trimmed chikens. Australian Veterinary Journal 69: 531-544.

13. Lindsay Oaks and Martin J (2004). Diclofenac residues as the cause of vulture population decline in Pakistan. Nature 1-4 Letters.

14. Martindale and Sean C Sweetman (2002). The Extra Pharmacopoeia, pp. 1564-1571.

15. Meteyer CU, Rideout BA, Gilbert M, Shivaprasad HL and Oaks JL (2005). Pathology and proposed pathophysiology of diclofenac poisoning in free living and experimentally exposed White-Backed Vultures (Gyps Bengalensis). Journal of wildlife diseases 41: 707-16.

16. Morgan G (1999). Benificial Effects of NSAIDS in the Gastrointestinal Tract. European Journal of Gastroenterology \& Hepatology 11: 393-400.

17. Oaks JL, Gilbert M, Virani MZ, Watson RT, Meteyer CU and Rideout BA (2004). Diclofenac residue as the cause of vulture population decline in Pakistan. Nature 427: 630-633.

18. Oliver JC and Birrenkott GP Jr (1981). Response of broilers to hyperthermic stress following treatment with a new cyclo-oxygenase inhibitor. Poultry Science 61: 1069-1072.

19. Ouellette, GS Slitzky, BE Gates, JA Lagarde and S West (1991). Reversible Hepatitis Associted with Diclofenac. Journal of Clinical Gastroenterology 2: 205-210.

20. Pain D (2003). Causes, effects of temperospatial declines of Gyps vultures in Asia. Conserv, pp. 661-671.

21. Patel AK, Ghodasara DJ, Dave CJ, Jani PB, Joshi BP, Prajapati KS(2007). Experimental studies on etiopathology of visceral gout in broiler chicks. Indian Journal of Veterinary Pathology 31: 24-8.

22. Perttunun K, Nilsson E and Kalso E (1999). IV Diclofenac Ketorolac for Pain after Thoracoscopic Surgery. British Journal of Anaesthesia 2: 221-227.

23. Reddy NC, Anjaneyulu Y, Sivasankari B, Rao KA (2006). Comparative toxicity studies in birds using nimesulide and Diclofenac sodium. Environmental Toxicology and Pharmacology 22: 142-7.

24. Snedecor GW and Cochran WG (1967). Statistical Methods. $6^{\text {th }}$ edition, New Delhi: Oxford and IBH.

25. Swan GE, Cuthbert R, Quevedo M, Green RE, Pain DJ and Bartels P (2005). Toxicity of Diclofenac to Gyps Vultures. Biology Letters 2: 279-82.

26. Taib, Jarrar NT and Mubarak BM (2004). Ultrastructural Alterations in Renal Tissues of Rabbits Induced by Diclofenac Sodium (Voltaren). Saudi Medical Journal 10: 1360-1365.

27. Tang W, Stearns RA, Bandiera SM, Zhang Y, Raab C and Braun MP (1999). Studies on cytochrome P-450 mediated bioactivation of diclofenac in rats and in human hepatocytes: Identification of glutathione conjugated metabolites. Drug Metabolism and Disposition 27: 365-72.

28. Uma CA, Vijayasarathi SK, Nalini TS, Satyanarayana ML and Rao S (1999). Pathology of gout in poultry. Indian J Veterinary Patholhology 23: 94-5. 